\title{
CLONAL CLEANING AND in vitro MULTIPLICATION OF Angelonia integerrima SPRENGEL
}

\author{
LIMPEZA CLONAL E MULTIPLICAÇÃO in vitro DE Angelonia integerrima \\ SPRENGEL
}

\author{
Mara Cíntia WINHELMANN ${ }^{1}$; Marília TEDESCO ${ }^{1}$; Priscila PARIS ${ }^{1}$; \\ Eduarda Demari AVRELLA ${ }^{1}$; Claudimar Sidnei FIOR ${ }^{1}$; Gilmar SCHAFER $^{1}$ \\ 1. Programa de Pós-Graduação em Fitotecnia, Universidade Federal do Rio Grande do Sul - UFRGS, - Porto Alegre, RS, Brazil
}

\begin{abstract}
The objective of this study is to test stem apex sizes in the in vitro establishing of Angelonia integerrima in order to obtain explants without by fungi and bacteria contamination for further multiplications. The treatments consisted of different stem apex sizes (1.0, 3.0, 5.0, 7.0, 9.0 and $11.0 \mathrm{~mm})$. At 45 and 90 days of cultivation, a count of contaminated explants and a count of shoots per explant formed were performed. In a second experiment, explants were cultivated in a medium containing different concentrations of benzylaminopurine (BAP) $(0.0,0.05,0.10$, 0.15 and $0.20 \mathrm{mg} \mathrm{L}^{-1}$ ). After 56 days of cultivation, the following variables were evaluated: shoot length, shoot fresh mass and number of shoots. During the explant establishment phase (45 days), only stem apexes with $1.0 \mathrm{~mm}$ in size were not contaminated. However, in the second subculture (at 90 days), only shoots from initial explants, with $7 \mathrm{~mm}$ in size or larger, were contaminated. Regarding multiplication, the presence of BAP showed a positive linear behavior for all variables. It is possible to obtain A. integerrima seedlings free of contamination in vitro by fungi and bacteria, using initial explants less than or equal to $5 \mathrm{~mm}$. IBA provided a linear increment for the multiplication of this species.
\end{abstract}

KEYWORDS: Pampa biome. Stem apex. Native ornamental. Plantaginaceae.

\section{INTRODUCTION}

Angelonia integerrima Sprengel can be found in open field areas, usually in dense and aggregate populations, in fields in the south of Brazil, Argentina, Paraguay and Uruguay (MARTINS et al., 2013). It is an herbaceous and perennial species, popularly known as "violeta-docampo" or "angelônia" and can reach $40 \mathrm{~cm}$ in height (BURKART, 1979; STUMPF et al., 2009). Flowering occurs from October to March; the flowers present well-defined raceme, with white to light lilac color, and some purple spots (BURKART, 1979; STUMPF et al., 2009). A. integerrima is a promising species, with ornamental potential, that can be used in flower arrangements, or cultivated in flowerbeds, flowerpots and pots (STUMPF et al., 2009).

Information on the most appropriate propagation methods is necessary for the domestication of the species. Among these methods, in vitro propagation can reduce the spread of diseases (MORAES et al., 2010). However, the in vitro establishment of the culture is a critical stage, since each species has its peculiarities in relation to genetic, physiological or environmental factors. Consequently, specific protocols need to be adjusted (TORRES et al., 1998).

During the in vitro establishment of the culture, considerable losses of the explants may occur due to microbial contaminations, mainly by fungi and bacteria, which are found on the surface of the tissues or even in the vascular system of the plant (endophytic) (MORAES et al., 2010). In practice, when no prior knowledge is available on the species, larger shoot tips are incubated by analysis of the contaminations obtained. The best explant to be used is determined at this stage (JUNGHANS; SOUZA, 2013). A. integerrima was subjected to preliminary tests during the in vitro establishment of approximately $1 \mathrm{~cm}$ explants, when the endophytic bacterium Methylobacterium aquaticum was identified by molecular analyses. This bacterium was detected in all explants, and when it was not present at the first stage of the in vitro test, colonies appeared on the medium soon after transferring the plants to a new medium.

To obtain in vitro pathogens-free plants, conventional methods can be used, such as the cultivation of shoot tips, that is, the excision of the apical meristem subjacent leaf primordial (from 0.3 to more than $20 \mathrm{~mm}$ ). The shoot tip contains the meristem, which is covered by several leaf primordia, and when placed in a suitable culture medium, develops into a complete plant (TORRES et al., 1998). The explant size is directly related to survival and regeneration capacity; however, the smaller the explant, the greater are the chances of obtaining in vitro pathogen-free plants. Therefore, the ideal explant size to be used for each species depends on the objective and on the purpose (VASIL; THORPE, 1994). 
The matrix plant must be kept in greenhouse to avoid the attack of pests and diseases (SHARMA et al., 2015). It can also be subjected to etiolation, by keeping the plant in the darkness, preventing chlorophyll formation. This procedure hinders the replication rate of the agent by making it lower than the shoot tip elongation rate, and consequently the explant is more likely to be free of contamination (TORRES et al., 1998). This practice is also used to reduce callus formation and to avoid injuries in the regeneration zone (JUNGHANS; SOUZA, 2013).

Several culture media can be used in experiments, and protocols can be adapted to be used in different species. The application of growth regulators is optional, but not necessary at the establishment stage. However, for some species, the use of cytokinins and auxins at low concentrations favors the growth and development of shoot tips (VASIL; THORPE, 1994). After the establishment of the culture, at the multiplication stage, the addition of synthetic cytokinin to the medium is fundamental, and benzylaminopurine (BAP) is the most used (VASIL; THORPE, 1994).

To obtain explants of Angelonia integerrima, free of in vitro bacterial and fungal contamination, the objective of this work was to test different sizes of shoot tips and the subsequent in vitro multiplication of shoots.

\section{CONTENTS}

Matrix plants of in vitro seed germination, collected from in situ propagative material in Barão do Triunfo (RS), were cultivated in $5 \mathrm{~L}$ pots containing commercial substrate Carolina Soil@, in a greenhouse. These plants were fertilized biweekly with $2 \mathrm{~g} \mathrm{~L}^{-1}$ of a formula containing NPK - 6-12-36 (Kristalon ${ }^{\circledR}$ amarelo), applied via fertigation, at the dose of $50 \mathrm{~mL}$ per pot. Drastic pruning was performed to stimulate the shoots. Afterwards, plants were placed in a dark chamber to obtain the etiolated shoots. At 30 days after cultivation, shoot tips were collected and immersed in deionized water with $1 \mathrm{~g} \mathrm{~L}^{-1}$ of ascorbic acid to avoid dehydration and oxidation of the plant material.

Explants were disinfected at the laboratory, with 1 minute in $70 \%$ alcohol, followed by 10 minutes in $1 \%$ sodium hypochlorite. Afterwards, in a laminar flow chamber, explants were triple rinsed in deionized and autoclaved water. The explants were kept in deionized and autoclaved water throughout the preparation process. Treatments consisted of different sizes of shoot tips $(1.0 ; 3.0$; 5.0; 7.0; 9.0 and $11.0 \mathrm{~mm}$ ) which were extracted with the aid of a magnifying glass.
The explants were placed in test tubes containing $10 \mathrm{~mL}$ of Murashige and Skoog (1962) medium (MS), plus $30 \mathrm{~g} \mathrm{~L}^{-1}$ sucrose, $7 \mathrm{~g} \mathrm{~L}^{-1}$ agar, and $0.1 \mathrm{mg} \mathrm{L}^{-1}$ benzylaminopurine (BAP). $\mathrm{pH}$ was corrected to 5.8 before autoclaving. The experiment consisted of a completely randomized design, with four replications of six tubes, and one explant per tube. The tubes were placed in darkness for seven days, and then kept in a growth room with $16 \mathrm{~h}$ photoperiod, at a temperature of 24 to $29{ }^{\circ} \mathrm{C}$, and light intensity of 27 to $33.75 \mu \mathrm{mol} \mathrm{m}^{-2} \mathrm{~s}^{-1}$.

Explants contaminated by fungi and bacteria and the number of shoots formed per explant were counted at 45 days after the beginning of the experiment. Contaminated explants were discarded and the others were removed from the tubes, individualized and established in the same culture medium as previously used. At 90 days, contaminated explants and the number of shoots formed per explant were counted again.Data were subjected to exponential regression by the statistical program SigmaPlot 11.0.

In a second experiment, the explants from the previous experiment were placed in MS medium plus $30 \mathrm{~g} \mathrm{~L}^{-1}$ of sucrose and $7 \mathrm{~g} \mathrm{~L}^{-1}$ of agar containing different concentrations of BAP: 0.0; $0.05 ; 0.10 ; 0.15$ and $0.20 \mathrm{mg} \mathrm{L}^{-1}$ for multiplication. The experiment consisted of a completely randomized design, with 19 replications, one flask per plot, and five explants per flask. Flasks were maintained in a growth room. At 56 days after cultivation, the following parameters were evaluated: shoot length, number of shoots, and shoot dry matter. Data were subjected to analysis of variance (ANOVA) and polynomial regression using the SigmaPlot 11.0 software. Shoot length and number of shoots were log-transformed $(\mathrm{x} / 10)$ to meet the ANOVA assumptions.

In the reading carried out at 45 days, the percentage of contamination increased with the increase in the size of the shoot tip (Figure 1A). All explant sizes showed in vitro contaminations, except for the smallest one. In the second subculture, that is, at the 90-day evaluation, only the larger shoots were contaminated. This fact demonstrates that these shoots still had endophytic microorganisms that appeared only in this subculture. Similar results were presented by Lima and Moraes (2006), who worked with in vitro multiplication of four banana varieties. The authors found that the highest contamination rate occurred shortly after establishment (subculture 0), and reduced in subsequent cultures. 

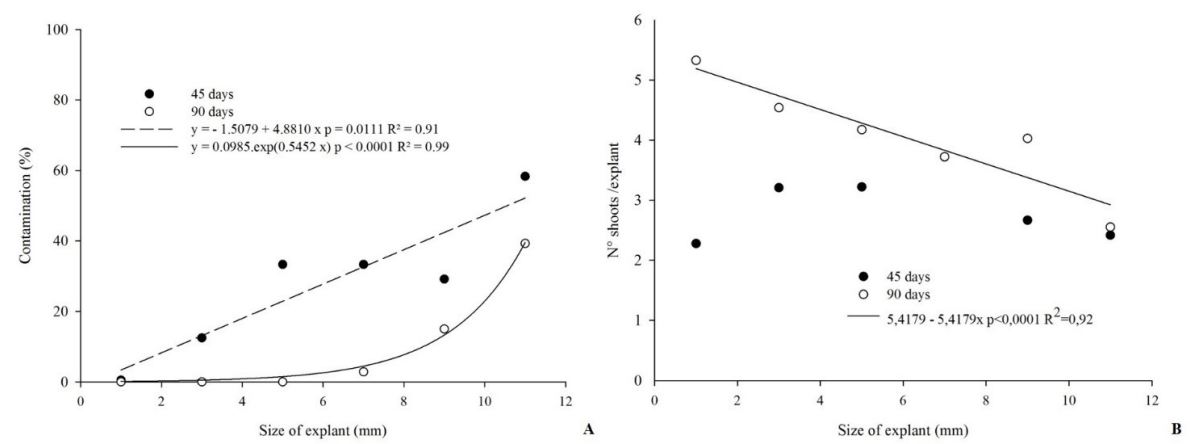

Figure 1. A) In vitro contamination of different explant sizes of Angelonia integerrima Sprengel at 45 and 90 days after cultivation; B) Number of shoots per explant at 45 and 90 days after in vitro cultivation of different sizes of shoot tips of Angelonia integerrima Sprengel.

The presence of endophytic microorganisms has been reported in several plant species, and the presence of fungi, yeasts and bacteria can be identified at the beginning of the cultivation process (SCHERWINSKI-PEREIRA，2010). The culture medium is suitable for the development of most microorganisms, but many of them may remain latent, especially bacteria, and may show no symptoms in the first subcultures, or no visible growth in the medium. These microorganisms compete for space and nutrients with the explants (SCHERWINSKI-PEREIRA, 2010). Preliminary tests have been performed with this species (data not shown), using $1 \mathrm{~cm}$ explants; when they presented no visual contamination, they were transferred to a new culture medium with the same initial composition. However, the bacterium was observed in the second subculture, and no in vitro contamination-free explants were obtained, which motivated this experiment.

The size of the explant is also related to its in vitro regeneration, that is, the capacity of in vitro organogenesis of each species. This means that the smaller the explant, the lower the regeneration rate. However, this relation is inversely proportional to the elimination of the endophyte microorganisms, as verified by Mwangangil et al. (2014) in the cultivation of Manihot esculenta crantz, where $44.44 \%$ of the explants with $1.0 \mathrm{~mm}$ in size could not regenerate, and of these, $88.2 \%$ had the virus eliminated. In the present study, 12.5 and $4.17 \%$ of explants with 1 and $3 \mathrm{~mm}$, respectively, did not regenerate, which can be considered as low.

The disinfestation process was efficient and proves that the smaller the explant, the lower is the contamination rate, since microorganisms live inside the leaf primordia that protect the meristem (JUNGHANS; SOUZA, 2013). Vegetative plant propagules are likely to host microorganisms; the larger the explant, the more plant tissue they have, and the greater are the chances of transmitting the pathogen to the new plant (KAYA; GOKDOGAN, 2015).

Figure 1B shows that even with the use of a low BAP concentration $\left(0.1 \mathrm{mg} \mathrm{L}^{-1}\right)$, multiplication was verified at the initial establishment, with a mean of 2.93 shoots per explant, regardless of the size. However, in the second subculture, the smaller the size of the initial explant, the more shoots were formed. These results are contradictory in relation to other works cited in the literature. For instance, in the in vitro establishment of Psychotria ipecacuanha (Brot.) Stokes, the authors verified that larger explants $(1$ and $1.5 \mathrm{~cm})$ had a greater number of shoots (2.64 times) when compared with smaller ones $(0.5 \mathrm{~cm})$ (REIS et al., 2004).

In a study with two cultivars of Catharanthus roseus, the authors verified higher regeneration rate in larger explants (7 to $9 \mathrm{~mm}$ ) in cultivar 'Sunstorm Rose'. For cultivar 'Pacific Coral', intermediate size explants (5 to $7 \mathrm{~mm}$ ) presented higher regeneration rate (SWANBERG; DAI, 2008). Only few studies have taken explant size into account in in vitro multiplication, since size is related to explant age (SWANBERG; DAI, 2008). Given the results, it is assumed that smaller explants were more stimulated by BAP at the establishment stage, since this regulator is close to the meristem. In larger explants, the meristem was more protected by the leaf primordia, which may have contributed to greater shoot formation.

In the second experiment, the variables analyzed responded positively to the BAP concentrations applied (Figure 2). The use of BAP increased the number of shoots per explant. The same was verified for the variable length and shoot fresh matter. Reduced concentrations of BAP were tested in this work, since in the in vitro establishment with $0.1 \mathrm{mg} \mathrm{L}^{-1}$ of BAP, the species 
presented high multiplication rate in the second subculture (at 90 days of evaluation) (Figure 1B).

Shoots were formed even without BAP application (Figure 2B). The presence of endogenous and exogenous cytokinin concentrations, being the latter used in the establishment and in the second subculture, may have assisted in the induction and subsequent shoot formation. To determine the optimum BAP concentration for the species multiplication, aiming at the maximum number of shoots per explant, higher BAP concentrations must be tested. The effect of cytokinins is not restricted to a subculture, and the residual effect of one subculture to another (TORRES et al., 1998), as well as the lower requirement of cytokinin for certain genotypes may be associated with high endogenous levels (RADMANN et al., 2009).

Cytokinins are beneficial to multiplication up to a certain concentration, and vary according to the species. Values higher than the optimum concentration may even be toxic (TORRES et al., 1998). In the present study, up to the maximum concentration used in this work, no toxic effect was verified, and up to 5.12 shoots per explants were obtained. Comparing with other species, such as Bouchea fluminensis (Vell.) Mold, 6.85 shoots per explant was obtained (RESENDE et al., 2014);
WINHELMANN, M. C. et al.

while 5.75 shoots per explant were obtained for Mentha $x$ piperita L., (ASMAR et al., 2011); and 3.3 shoots per explant were obtained for Etlingera elatior Jack RM Sm. (COLOMBO et al., 2010). This fact confirms that the number of shoots per explants varies among species, and thus the number of shoots per explants reported for A. integerrima can be considered as an acceptable value.

In relation to shoot length, the maximum BAP concentration had a positive increase over the analyzed variables, because the concentrations of endogenous cytokinins promote the growth of the shoot by the increase of the cellular proliferation in the apical meristem (TAIZ; ZEIGER, 2013).

The initial stage, that is, the establishment of the in vitro culture, was considered as the most complex due to the presence of endophytic microorganisms. Thus, this stage required feasible strategies, since disinfestation process alone was not efficient, with $100 \%$ contamination in preliminary studies. However, when disinfestation was associated with the extraction of small shoot tips, explants smaller than or equal to $5 \mathrm{~mm}$ did not show any visible contamination by the bacteria. Moreover, slightly larger explants $(5 \mathrm{~mm})$ presented higher regeneration rates and were easier to be successfully extracted when compared with smaller ones.
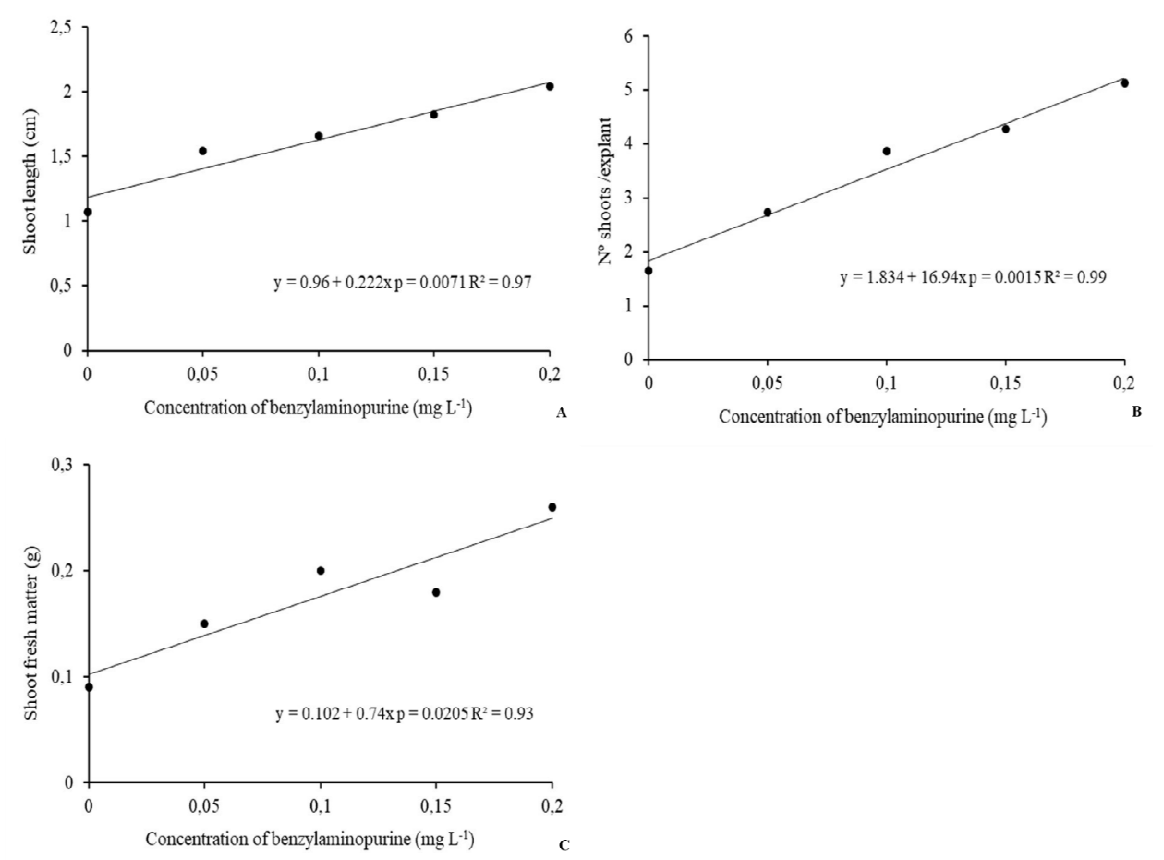

Figure 2. A) Shoot length (cm); B) mean number of shoots formed per explant; C) Shoot fresh matter (g) in the in vitro propagation of Angelonia integerrima Sprengel under concentrations of benzylaminopurine (BAP). 
A. integerrima plants free of in vitro contamination by fungi and bacteria can be obtained using initial explants smaller than or equal to $5 \mathrm{~mm}$.
BAP provided linear increase for species multiplication.

RESUMO: O objetivo do trabalho foi testar tamanhos de ápices caulinares no estabelecimento in vitro de Angelonia integerrima, a fim de obter explantes sem contaminações por fungos e bactérias para posterior multiplicação. Os tratamentos consistiram de tamanhos de ápices caulinares: 1,0; 3,0; 5,0; 7,0; 9,0 e 11,0 mm. Após 45 e 90 dias de cultivo foi realizada a contagem de explantes contaminados e o número de brotos formados por explante. Em um segundo experimento, explantes foram cultivados em meio contendo diferentes concentrações de benzilaminopurina (BAP): 0,0; 0,$05 ; 0,10 ; 0,15$ e $0,20 \mathrm{mg} \mathrm{L}^{-1}$. Após 56 dias de cultivo foram avaliados: comprimento e massa fresca da parte aérea e número de brotos. Durante a fase de estabelecimento (45 dias), somente explantes com 1,0 mm não apresentaram contaminação, já no segundo subcultivo (aos 90 dias) somente brotações oriundas de explantes com tamanho inicial igual ou superior a $7 \mathrm{~mm}$ apresentaram contaminação. Com relação à multiplicação, a presença de BAP apresentou comportamento linear positivo para todas as variáveis analisadas. É possível obter mudas de A. integerrima livres de contaminações in vitro por fungos e bactérias, utilizando explantes iniciais menores ou iguais a $5 \mathrm{~mm}$. O BAP proporcionou incremento linear para a multiplicação da espécie.

PALAVRAS-CHAVE: Bioma Pampa. Ápice caulinar. Ornamental nativa. Plantaginaceae.

\section{REFERENCES}

ASMAR, S. A.; RESENDE, R. F.; ARARUNA, E. C.; MORAIS, T. P.; LUZ, J. M. Q. Citocininas na multiplicação in vitro de hortelã-pimenta (Mentha x piperita L.). Revista Brasileira de Plantas Medicinais, Botucatu, v. 13, n. SPE, p. 533-538, 2011.

BURKART, A. Flora Ilustrada de Entre Rios (Argentina). Parte V: Dicotiledoneas Metaclamideas. Buenos Aires: INTA, 1979. 606 p.

COLOMBO, L. A.; ASSIS, A. M. de; FARIA, R. T. de; ROBERTO, S. R. Estabelecimento de protocolo para a multiplicação in vitro de Bastão-do-imperador (Etlingera elatior) Jack RM Sm. Acta Scientiarum.

Agronomy, Maringá, v. 32, n. 4, p. 695-700, dez. 2010.

JUNGHANS, T. G.; SOUZA, A. da S. Aspectos práticos da micropropagação de plantas. 2. ed. rev. e ampl. Brasília, DF: Embrapa, 2013. 407 p.

KAYA, E.; GOKDOGAN, E. Y. Virus eradication from plants via novel biotechnological processes: one step freezing methods based on vitrification of cryotherapy techniques. Mugla Journal of Science and Technology, v. 1, n. 2, p. 34-40, 2015. https://doi.org/10.22531/muglajsci.210008

LIMA, J. D.; MORAES, W. da S. Concentração de benzilaminopurina e avaliação de protocolo para multiplicação in vitro de genótipos de bananeira. Pesquisa Agropecuária Tropical (Agricultural Research in the Tropics), Goiânia, v. 36, n. 1, p. 13-19, 27 out. 2006.

MARTINS, A. C.; AGUIAR, A. J. C.; ALVES-DOS-SANTOS, I. Interaction between oil-collecting bees and seven species of Plantaginaceae. Flora - Morphology, Distribution, Functional Ecology of Plants, v. 208, n. 7, p. 401-411, jul. 2013. https://doi.org/10.1016/j.flora.2013.07.001

MORAES, C. F.; SUZIN, M.; NIENOW, A. A.; GRANDO, M. F.; MANTOVANI, N.; CALVETE, E. O.; DONIDA, B. T. Germinação in vitro de sementes de alcachofra. Horticultura Brasileira, Campinas, v. $28, \mathrm{n}$. 1, p. 64-69, mar. 2010. https://doi.org/10.1590/S0102-05362010000100012

MURASHIGE, T.; SKOOG, F. A revised medium for rapid growth and bio assays with tobacco tissue cultures. Physiologia Plantarum, Copenhagen, v. 15, n. 3, p. 473-497, 1 jul. 1962. https://doi.org/10.1111/j.13993054.1962.tb08052.x 
MWANGANGI, M.; ATEKA, E.; NYENDE, A.; KAGUNDU, A. Elimination of Cassava Brown Streak Virus from Infected Cassava. Journal of Biology, Agriculture and Healthcare, New york, v. 4, n. 13, p. 34-40, 2014.

RADMANN, E. B.; BIANCHI, V. J.; OLIVEIRA, R. P. de; FACHINELLO, J. C. Multiplicação in vitro e alongamento das brotações micropropagadas do porta-enxerto 'Tsukuba 1' (Prunus persica L.). Revista Brasileira de Fruticultura, v. 31, n. 3, p. 656-663, set. 2009. https://doi.org/10.1590/S0100-

29452009000300006

REIS, É. S.; PINTO, J. E. B. P.; CORRÊA, R. M.; BERTOLUCCI, S. K. V.; LAMEIRA, O. A. Tamanhos e posições de explantes e volumes de meio de cultivo na multiplicação de ipeca (Psychotria ipecacuanha (Brot.) Stokes) in vitro. Ciência e Agrotecnologia, Lavras, v. 28, n. 3, p. 703-709, jun. 2004.

RESENDE, C. F.; BRAGA, V. F.; SILVA, C. J. da; PEREIRA, P. da F.; RIBEIRO, C.; SALIMENA, F. R. G.; PEIXOTO, P. H. P. An efficient system for in vitro propagation of Bouchea fluminensis (Vell.) Mold.

(Verbenaceae). Acta Botanica Brasilica, São Paulo, v. 28, n. 2, p. 184-189, jun. 2014.

https://doi.org/10.1590/S0102-33062014000200005

SCHERWINSKI-PEREIRA, J. E. (Ed.). Contaminações microbianas na cultura de células, tecidos e órgãos de plantas. Brasília, DF: Embrapa Informação Tecnológica, 2010. 446 p.

SHARMA, G. K.; JAGETIYA, S.; DASHORA, R. General techniques of plant tissue culture. North Carolin: Lulu Press Inc. Raleigh, 2015. 30 p.

STUMPF, E. R. T.; BARBIERI, R, L.; HEIDEN, G. Cores e formas no Bioma Pampa: plantas ornamentais nativas. Pelotas: Embrapa Clima Temperado, 2009. 276 p.

SWANBERG, A.; DAI, W. Plant regeneration of periwinkle (Catharanthus roseus) via organogenesis.

HortScience, Alexandria, v. 43, n. 3, p. 832-836, 1 jun. 2008.

TAIZ, L.; ZEIGER, E. Fisiologia Vegetal. 5. ed. Porto Alegre: Artmed, 2013. 919 p.

TORRES, A. C.; CALDAS, L. S.; BUSO, J. A. Cultura de Tecidos e Transformação Genética de Plantas.

Volume. 1. Brasília: Embrapa-SPI/Embrapa-CNPH, 1998. 864 p.

VASIL, I. K.; THORPE, T. A. Plant cell and Tissue Culture. Dordrecht: Kluwer, c1994. 593 p. 